would appear that the differences here noticed in the Char are chiefly induced by locality, but this, in itself, is rather an effect than a cause. The cause is, I conceive, based on geological influences, as the "formation" in which the lake inhabited by this fish is situated, and whether there be a prevalence of rock, gravel, sand, or peat-if fed by springs or a goodly river, and if the latter the formation through which it flows - the depth of water, \&c. According to these features, the quality of the water, and the minute animals constituting the food of the Char will vary, and the latter not only in the quantity produced, but in species. According to its food the external appearance of this fish is influenced, as well as the flavour and colour of its flesh. No proper comparison, again, can in any respect be made between the Char of different localities unless the examples be in similar condition, and which, as before mentioned, they sometimes are not in adjacent lakes at the same period of the year. A great deal might be said on the manifold influences affecting this species, but it is for my friends, the authors of the two great works now in progress-M. Agassiz in his ' Freshwater Fishes of Central Europe,' and Sir W. Jardine in his 'Scottish Salmonidæ' - to descant upon them.

When my attention was first given to this subject, I intended to enter fully into the history of the Char as a British species. This would now be superfluous, and I content myself with contributing the rough notes made upon the subject, as ere long we shall doubtless have before us, in the works just mentioned, a most ample history of the Salmo Umbla.

LII.-A List of Mammalia and Birds collected in Assam by John McClelland, Esq., Assistant Surgeon in the service of the East India Company, Bengal Establishment : revised by T. Horsfield, M.D., V.P.L.S., \&c.*.

[Concluded from p. 374.]

Order II. INSESSORES, Vigors.

Tribus Fissirostres, Cuv.

Fam. Meropide.

Genus Nyctionnis, Swains. Zool. Illust. II. Pl. 56.

9. Nyetiornis Athertonii.

"Toes much longer than the tarsi; outer ones united to the last

* Communicated by Dr. Horsfield to the Zoological Society of London, Oct. 22, 1839, and extracted from the Proceedings of the Society. 
joint, and the inner to the first joint: beak compressed, arched equally from the forehead, and terminating in a point formed by both mandibles: nostrils concealed with feathers : body seven, tail five inches long."-McClelland's MS.

\section{Fam. Hirundinide.}

Genus Hirundo, Auct.

10. Hirundo brevirostris. Suprà nigricans nitore olivaceo; subtùs fuscescens, alis elongatis ; caudd mediori subfurcatâ; rostro brevissimo.

This species agrees with Hirundo fuciphaga in habit, in proportional length of wing, and shortness of beak, and in colour above; but it is darker underneath, and more than one third larger : entire length six inches.

11. Hirundo Jewan, Sykes, Proceed. Zool. Soc. 1832, p. 83.

The specimens of this bird sent from Assam by Mr. McClelland agree in all points with those discovered in Dukhun by Col. Sykes.

12. Hirundo brevicaudata. Suprà fusca; subtìs cana; uropygio albido; caudá brevissimá subcequali.

This species has the general physiognomy of the Hir. concolor, Sykes, but it is considerably smaller, of a lighter tint, and without the white spots on the tail which mark that species.

\section{Fam. Todid E.}

Genus Eurylaimus, Horsf.

13. Eurylaimus lunatus, Gould, Trans. Zool. Soc. of London, I. 175.

The specimens forwarded by Mr. McClelland from Assam agree with those preserved in the Museum of the Zoological Society, which have been examined and marked by Mr. Gould.

14. Eurylaimus Dalhousia, Jamieson, Edin. New Phil. Journ., vol. 18, p. 389. Psarisomus Dalhousia, Swainson, Cab. Cyclop. Birds, Vol. II. 261. Royle's Illustr., Part VI. Pl. 7.

Eurylaimus Psittacinus, Tem. Pl. Col. 598.

Eurylaimus (Crossodera) Dalhousia, Gould, 'Icones Avium,' Part I. Aug. 1837.

"Above grass-green, beneath light bluish-green; throat yellow; crown velvet-black, with blue and yellow spots; quills black on their inner margins, but anteriorly light blue in the middle of the wings ; tail slender, light blue above, beneath black; length nine inches."Mc Clelland's MS.

Fam. Halcyonide.

Genus Alcedo, Linn.

15. Alcedo Bengalensis, Gmel. Linn. I. 450. Little Ind. Kingfisher, Edw.

16. Alcedo rudis, Linn. I. 181. Black and White Kingfisher, Edw. 
Genus Halcyon, Swains.

17. Halcyon Smyrnensis. Alcedo Smyrnensis, Linn. I. 181.

18. Halcyon leucocephala, Gmel. Linn. I. 456.

Tribus Dentirostres, Cuv.

Fam. Muscicapide.

Genus Phoenicornis, Sw.

19. Phonicornis princeps. Muscipeta princeps, Gould's Cent. of Himal. Birds, Pl. VII.

20. Phoenicornis brevirostris. Muscipeta brevirostris, Gould's Cent., Pl. VIII. The male.

21. Phonicornis elegans. Capite elongato, sincipite admodum compresso ; capite, collo, dorso summo, alis, rectricibusque duabus mediis nigris; corpore subtùs, dorso imo, fasciâ latâ alarum, maculis paucis apud remiges secundarios, rectricibusque lateralibus aurantio-coccineis.

The character given by Mr. Gould of the Phoenicornis (Muscipeta) princeps, as far as regards the nature and distribution of its colours, applies also to the Ph.elegans, but the latter is somewhat less in size, while it is chiefly distinguished by the flatness of the crown, which brings it nearly on a plane with the upper mandible. Mr. McClelland has given on one sheet a comparative view of the Phon. elegans, princeps, and brevirostris, in order to illustrate the form of the head in each species, and the depression of the sinciput in Phoen. elegans, in which its essential difference consists.

22. Phonicornis affinis. Capite colloque suprà cum regione interscapulari griseis; collo subtùs gastræo, dorso imo, maculis tribus alarum, rectricibus interioribus ad basin exterioribus totis flavis : alis caudâque in medio nigris.

"The male is larger than the female, and distinguished from her by a yellow band on the forehead between the eyes."-McClelland's IMS.

Mr. Gould has figured this bird as the female of Phoen.brevirostris, but by annexing a mark of interrogation to the specific character, has indicated his doubt respecting the correctness of his determination, or its being really a distinct species. This doubt has now been explained by the researches of Mr. McClelland in its native country.

Genus Muscicapa, Auct.

23. Muscicapa melanops, Vigors, Proceed. Zool. Soc. 1831, 171; Gould's Cent. of Himal. Birds, Pl. VI.

24. Muscicapa? capitalis. Capite suprà tectricibus primariis, rectricibusque suprà atris; maculá suboculari utrinque ad occiput productâ albâ; subtùs, dorso lateribusque colli saturatè fuscis ; crisso et uropygio canis.

The distinctive character of this species rests on a very concise description of Mr. McClelland, accompanied by a drawing : no perfect specimen was found in the collection. Length five inches. 
Genus Rhipidura, Vigors \& Horsf.

25. Rhipidura fuscoventris, Frankl., Proceed. Zool. Soc. 1831, 117, Broad-tailed Fly-catcher, Lath.?

Genus Cryptolopha, Swains. Nat. Lib. Ornith. Vol. X., Flyeatchers.

26. Cryptolopha poiocephala, Sw., loc. cit. p. 200. PI. XXIII. Platyrhynchus Ceylonensis, Swains. Zool. Illust., I. 13.

Fam. Laniade, Vigors.

Genus Artamus, Vieill.

27. Artamus leucorhynchos, Vieill. Lanius leucorhynchos, Linn. Mantis. (1771) p. 524.

Genus Dicrurus, Vieill.

28. Dicrurus grandis. Edolius grandis, Gould, Proceed. Zool. Soc. 1836, p. 5 .

Several specimens of this bird received from Assam agree with the specific character and description given by Mr. Gould (as above cited) in all points excepting the size, being about one-third smaller; but further observations are required to determine with precision the points by which the long-tailed Edolii are to be discriminated.

29. Dicrurus Rangoonensis. Edolius Rangoonensis, Gould, Proceed. Zool. Soc. 1836, p. 5 .

One of our specimens agrees accurately with Mr. Gould's specific character; in two others the crest is less developed, and the lanceolated plumes on the throat are less prominent.

30. Dicrurus Balicassius, Vieill., Enc. Méth. Ornith., 751. Corvus Balicassius, Linn. Syst. I. p. 155 . Le Drongo Balicasse.

31. Dicrurus aneus, Vieill., Enc. Méth. Ornith., 751. Le Drongo Bronzè.

\section{Genus Trichophorus, Temm.}

32. Trichophorus flaveolus, Gould, Proceed. Zool. Soc. 1836, p. 6 .

"Yellowish-green above, with a tinge of brown on the wings and tail; beneath bright yellow : crested with narrow feathers, becoming progressively longer from the nostrils to the crown ; bill strong, compressed, and slightly hooked; cheeks and nucha scantily covered with feathers. Eight inches long."-McClelland's MS.

The specimens sent from Assam agree with those contained in the Museum of the Zool. Society from the Himalaya, which are the originals of Gould's description.

\section{Genus Collurio, Vigors.}

33. Collurio nigriceps, Frankl., Proceed.Zool. Soc. 1831, p. 117. Indian Shrike, Lath.

"Crown, nape, tail, and wings black; throat and breast white; body and secondaries reddish-gray. Length nine inches."-Mc Clelland's MS.

34. Collurio erythronotus, Vigors, Proceed. Zool. Soc. 1831, p. 42. Gould's Century of Himal. Birds, Pl. XII. fig. 2. 
"This species, as found in Assam, compared with the figure in Gould's Century of Himalayan Birds, is considerably smaller, and the colours more dull in the Assam than in the Himalayan bird. I am therefore disposed to think that the species has here reached its south-eastern geographical limit, as the Irena puella may be supposed in Assam to have reached its northern limit."-McClelland's MS.

Genus Hypsipetes, Vigors, Proceed. Zool. Soc. 1830-1, p. 43.

35. Hypsipetes McClellandir, Horsf. Suprà olivaceo-viridis; capite subcristato vinaceo-fusco, plumis albicante strigatis; subtìs vinacea, abdomine pallidiore; gulâ albidâ, plumis laxis lanceolatis; rostro flavicante.

"Head brown; body and tail above yellowish-green; beneath vinaceous-gray, the tints of the abdomen being lighter. (Plumes of the throat white, lanceolate, and straggling, being bedded in a bluish down.) Inner vanes of the quills brownish-black; tarsi slender, and rather short. Length nine inches."-McClelland's MS.

36. Hypsipetes psaroides, Gould's Century of Himal. Birds, Pl. X.

37. Hypsipetes gracilis. Suprà olivaceo-cinerea, crisso pallidiore; subtùs ex diluto cinnamomeo albicans; capite summo atro; remigibus primoribus atris, vexillis exterioribus tenuiter cano marginatis, secundariis canis margine nigro; rectricibus ex diluto olivaceo canescentibus, fasciâ latâ subterminali nigrâ in exterioribus gradatim latiore.

This species deviates slightly from the character of Hyps. psaroides, the type which served for the definition of the genus, and gradually approaches that of Kittacincla of Gould.

\section{Genus Graucalus, Cuv.}

38. Graucalus maculosus. Coerulescenti-canus, alis caudaque saturatioribus obscuro olivaceo nitentibus; rectricibus exterioribus albo apiculatis.

"Olive-black on the wings and tail; body above dark olive-gray, with light gray longitudinal streaks on the feathers under the throat, and light wavy lines on the abdomen and vent; outer tail-feathers with white tips. Length eight and a half inches."-McClelland's MS.

\section{Fam. Merulide.}

Genus Ianthocincla, Gould, Proceed. Zool. Soc. 1835, p. 187.

39. IAnthocincla gularis. Capite suprà pectoreque coerulescenti cinereis ; notco, abdomine, femoribus, rectricihusque exterioribus latè cinnamomeis in aurantium vergentibus; dorso saturatiore; rectricibus intermediis nigricantibus; strigd aterrima a rostri basi sub oculos ad regionem paroticam producta; gula tarsisque flavicantibus; rostro nigro.

"Head ash-gray, with a black band passing along the eyes; throat yellow; breast gray; rest of the body light olivaceous-brown, inclining to reddish-yellow; beak compressed, arched above a little more than below, depressed at the point; tarsi strong, longer than the 
middle toe, and yellow; wings rather short and round."-McClelland's MS.

This bird, although greatly resembling the Ianthocincla albogularis of Gould, is clearly distinguished from that species by the yellow colour of its throat, by the absence of the white tips to the exterior tail-feathers, by its yellow tarsi, and by the brighter orange shade of its general tint.

40. Ianthocincla pectoralis, Gould, Proc. Zool. Soc. 1835, p. 186.

"Above greenish-brown, beneath yellow and white, irregularly intermixed. A black band extends over each eye, descending on the sides of the neck, unites (from each side) in front of the neck; throat yellowish-white; lower tail-feathers tipped with white; beak compressed, slightly arched above; upper mandible projecting and slightly depressed at the tip; tarsi high and strong."-McClelland's MS.

41. Ianthocincla lunaris. Cinnamomeo-olivacea, capite summo caudaque nigricantibus; fronte, gutture pectoreque in medio atris ; lunulâ insigni collari a regione parotica gulam versus extensd crissoque lątè ferrugineis.

"Dark olive; throat and lores black, bounded posteriorly by a light brown crescent; vent and a few clouds on the abdomen of the same colour; tail blackish; wings short, and chiefly concealed beneath the downy plumage of the back; tarsus strong, longer than the middle toe; beak arched beneath, compressed, slightly denticulated, but not hooked. Length nine inches."-McClelland's MS.

Genus Oriolus, Auct.

42. Oriolus melanocephalus, Gmel. Linn. I. 383. Black-headed Oriole, Lath.

43. Oriolus Traillii. Pastor Traillii, Gould's Cent. Himal. Birds, Pl. XXXV.

Genus Irena, Horsf.

44. Irena Puella, Horsf., Linn. Trans., XIII. p. 153. Coracias Puella, Lath. Ind. Orn. 171.

\section{Genus Ixos, Temm.}

45. Ixos monticola. "Above grayish-brown; crown black and crested; throat and abdomen white; vent searlet; lower tail-feathers tipped with white; wings short; body four inches, tail three inches long, and square; a scarlet ring about the eye, but no red tuft beneath this organ; by the latter circumstance it differs from Ixos jocosus.

"Inhabits the Kossia mountains, and usually seen in numerous flocks, flying from tree to tree in quest of insects. Their note is shrill and inharmonious, not unlike that of the sparrow."-McClelland's $\boldsymbol{M S}$.

Further observations are required to determine the rank of this bird as a distinct species, or as a variety of Ixos jocosus.

46. Ixos Cafer. Turdus Cafer, Linn. I. 295. Le Curouge, Le Vaill. 


\section{Genus Timalia, Horsf.}

47. Timalia pileata, Horsf., Linn. Trans., XIII. p. 151.

"This is another instance of a species of the Malayan Archipelago having extended itself to Assam, and is more interesting from the smallness of its size, its length being only five and a half inches in Assam, but in Sumatra and Java it is six and a half inches in length. The tail in the Assam variety is marked with obscure bands, which does not appear to be the case with the Java variety ; and the plumes of the belly and thighs are shorter in the former than in the latter." $-M c$ Clelland's MS.

Genus Geocichla, Kuhl.

48. Geocichla Rubecula, Gould, Proceed. Zool. Soc. 1836, p.7.

Fam. Sylviade.

Genus Motacilla, Auct.

49. Motacilla variegata, Steph. Pied Wagtail, Lath. Mot. picata, Frankl.

Genus Saxicola, Bechst.

50. Saxicola Rubicola, Temm.

51. Saxicola? olivea. Supra olivaceo-viridis, subtùs ex plumbeo corulescens; fronte flavicante.

"A minute species, olive-green above, leaden-blue beneath, and olive-yellow on the forehead; anterior toes short; tarsi elevated. Iength three inches."-McClelland's MS.

A single specimen only has been forwarded, which is not sufficiently perfect to determine its true generic character with certainty.

Genus Phoenicura, Jard. \& Selb.

52. Phonicura Reevesii, Gray, Zool. Misc.

Genus Zosterops, Vigors and Horsf.

53. Zosterops Maderaspatanus? Catal. of Zool. Specim. Append. to Life of Sir T. S. Raffles, p. 661.

The specimen sent home by Mr. McClelland differs from that brought from Sumatra by Sir T. S. Raffles in being a trifle smaller.

Fam. Piprider.

Genus Parus, Linn.

54. Parus atriceps, Horsf., Trans. Linn. Soc., XIII. 160.

55. Parus flavocristatus, De Lafresnage. Mésange à huppe jaune. Guerin, Mag. Zool., Pl. 80. Janvier 1837. Parus Sultaneus, Hodgson, India Review and Journal of Foreign Science, \&c., by F. Corbyn, Esq., April 1837.

"The female is distinguished from the male by the black colour being less intense, and intermixed more with a greenish tint. For the first specimen of this elegant bird I was indebted to Mr. Griffith, who procured it during our descent from the Kossia mountains 
into Assam, in which place, however, they are more common."Mc Clelland's MS.

\section{Genus Leiothrix, Swains.}

56. LeIothrix̄LEPIDA. Capite subcristato suprà nucháque cinereis in ccerulescentem vergentibus ; dorso tectricibusque alarum ex olivaceo cinnamomeis ; alis cauddque suprà ex parte coruleis ; remigum pogoniis internis latè nigris, apicibus albis; rectricibus exterioribus pogoniis internis, omnibus apicibus albis : subtùs ex diluto cinnamomeo canescens.

"Gray; bluish on the crown, brownish on the back, and light bluish-gray beneath; wings and tail blue (inclining to black), with minute white tips and light blue outer margins. Length five inches." -Mc Clelland's MS.

57. Leiothrix signata. Olivaceo-fusca abdomine pallidiore; alis, cauddque subcastaneis ; guld obsoletè flavicante; fascid collari ex latè-cyaneo nitente.

"Olive-brown above, lighter beneath; a Prussian-blue streak on each side of the neck; tail short and square. Length five inches".Mc Clelland's MS.

58. Leiothrix ornata. Capite colloque suprd nigricantibus; subtùs taniaque ad latera colli per oculos ad rostrum ductd albis; noteo cinnamomeo, crisso pallidiore; alis cauddque nigris remigibus secundariis albo marginatis, primoribus rectricibusque ad apices albo limbatis, omnibus nitore cruento inductis.

"Head black, with a white streak passing over each eye; back brown; wings and tail black, variegated with scarlet and white; beneath white."-McClelland's $\boldsymbol{M S}$.

\section{Tribus Conirostres, Cuv. \\ Fam. Fringillide, Vigors. \\ Genus Mirafra, Horsf.}

59. Mirafra Assamica. Corpore cinereo-brunneo variegato, uropygio pallidiore; remigum pogoniis internis caudaque basi rufis; subtùs ex rufescente cana, plumis pectoris'nigro maculatis ; lunuld obsoletè fuscd temporibus.

This species appears to be intermediate between Mirafra Javanica, Horsf., and Mirafra phonicura, Frankl., but its characters are sufficiently marked to distinguish it from both.

60. Mirafra Flavicollis. Suprà olivaceo-brunnea, vertice saturatiore, tectricibus secundariis albicante marginatis; subtìs flava, fasciis paucis obsoletè fuscis ; crisso cauddque subtùs albicantibus.

Length five inches.

Genus Ploceus, Cuv.

61. Ploceus Manyar. Fringilla Manyar, Horsf., Trans. Linn. Soc., XIII. p. 160.

Genus Lonchura, Sykes, Proceed. Zool. Soc., 1832, p. 94. 
62. Lonchura melanocephala. Capite, collo, pectoreque atris; corpore, alis cauddque saturatè badiis.

Length four inches.

63. Lonchura Cheet, Sykes, Proceed. Zool. Soc., 1832, p. 95.

Fam. Sturnid

Genus Pastor, Temm.

64. Pastor tristis, Temm. Gracula tristis, Lath., Ind. Orn., I. 190. 65. Pastor Pagodarum, Temm. Turdus Pagodarum, Gmel. Linn.

Genus Lamprotornis.

66. Lamprotornis spilopterus, Gould's Cent. of Himal. Birds.

\section{Fam. Corvide.}

Genus Corvus, Linn.

" The Raven, the Carrion Crow, and the Rook, are inhabitants of Assam, but are seldom found in the depths of the forests. They rather follow the footsteps of man, and establish themselves in small numbers in the vicinity of villages and such places on the banks of rivers as are frequented by travellers as halting-places. The Hooded Crow is very common, but I did not perceive anything peculiar about it to induce me to add it to my collection."-McClelland's MS.

Genus Dendrocitta, Gould, Proceed. Zool. Soc., 1833, p. 57.

67. Dendrocitta frontalis. Facie aterrima, conterminio exactè circumscripto, alis caudaque nigris; occipite, vertice, collo, pectoreque albis, diluto canescente lavatis; humeris, notao, hypochondriis, femoribusque badiis in ferrugineum vergentibus; tectricibus secundariis saturato corulescenti-canis.

Length of the body seven, of the tail ten inches.

68. Dendrocitta vagabunda, Gould's Cent. Himal. Birds. Pica vagabunda, Vieill., Encyclop. Méthod. Ornitholog., p. 888 . Coracias vagabunda, Lath., Ind., I. 171.

\section{Genus Kitta,}

69. Kitta venatorius, Gray, Illustrations of Indian Zoology, I. Pl. XXIV.

\section{Genus Coracias, Linn.}

70. Coracias Affinis. Capite suprà aruginoso, nucha dorsoque olivaceis, ceneo subnitentibus; fascia alarum latd, tectricibus utrinque, rectricibus ad basin, salvis intermediis glaucis, saturatissimè cyaneis; fascid remigum primorum subterminali, secundariarum basali, uropygio, fascia lata terminali rectricum, crissoque latè thalassinis: subtus et lateribus colli vinaceis ; guld plumis laxis, in medio violaceo-vittatis, ornatd.

Genus Gracula.

71. Gracula religiosa, Linn. Syst., I. p. 164. 
Fam. Bucerid

Genus Buceros, Linn. Lath.

72. Buceros Malabaricus, Gmel. Linn., I. 359. Pied Horn-Bill,

73. Buceros Homrâi, Hodgson, Journ. As. Soc. Bengal, Vol. I. p. 251.

Mr. Hodgson's description of the Buceros Homrâi applies closely to Mr. McClelland's specimens, and also to the bird figured in the 44th plate of Gould's Century of Himalayan Birds, and to specimens from Sumatra in the East India Company's Museum; while the Calao à casque concave of Le Vaillant, according to Dr. Shaw's description and specific character, differs in various particulars.

Fam. Loxiade, Vigors.

Genus Paradoxornis, Gould, Proceed. Zool. Soc., 1836, p. 17.

74. Paradoxornis flavirostris, Gould, loc. cit., figured in Gould's 'Icones Avium,' Part I. Bathyrhynchus brevirostris, McClelland, Quarterly Journal of the Calcutta Med. and Phys. Sỏciety, Dec. 1837. With a figure.

"Brown, beneath yellowish-brown; head brown, with a black circle under each eye, the interior feathers of which have white tips; wings short; beak much compressed, strong, shorter than its depth, and thrice the depth of its breadth at the base; mandibles equally arched, and meeting in front, without a hook, in an obtuse point ; nostrils small, round, and concealed by recurved feathers."-McClelland's $M S$.

Tribus Scansores.

Fam. Psittacide.

Genus PaLmornis, Vigors.

75. Palcornis torquatus, Vigors. Psittacus torquatus, Auct.

76. Palcornis Pondicerianus, Vigors. Psittacus Pondicerianus, Auct.

Fam. Picide.

Genus Bucco, Auct:

77. Bucco corvinus, Temm. Pl. Col. DXXII.

78. Bucco cyanops, Cuv. Capito cyanocollis, Vieill., Gal. des Ois. XXXV.

Genus Picus, Linn.

79. Picus strenuus, Gould.

80. Picus occipitalis, Gould's Cent. of Himal. Birds, Pl. XLVII.

81. Picus Nepalensis, Gray and Hardw. Ind. Zool., PI. XXXI. Fig. 1.

82. Picus Macei, Temm. Pl. Col. LIX.

83. Picus (Chrysonotus, Swainson) Grantia. Fronte, alis, caudaque suprà ex sordidè aurantio rufescentibus; collo suprà et ad latera ex viridi flavicante; subtùs fuscus; rectricibus flavicante 
fasciatis; remigibus primoribus fuscescentibus, vexillis alternis flavo-guttatis vel fasciatis.

Length nine inches.

This bird belongs to Mr. Swainson's subgenus Chrysonotus, Lard. Cab. Cycl. Birds, II. p. 309, of which Picus Tiga, Linn. Tr., XIII. 177 , is given as the type.

84. Yunx torquilla, Linn.

Genus Yunx, Linn.

The specimens collected by Mr. McClelland agree in all points with the bird as found in Europe.

\section{Fam. Certhiade. \\ Genus Sitta, Linn.}

85. Sitta frontalis, Horsf., Linn. Trans., Vol. XIII. p. 162.

86. Upupa Epops, Linn.

Genus Upupa, Linn.

From comparison with European specimens, it appears that this bird, as occurring in Assam, can scarcely be considered a variety of the $U$. Epops of Linnæus; although Mr. McClelland's specimens are rather smaller, they do not agree with the $U$. minor of Shaw, which is found in Africa,

\section{Genus Pomatorhinus, Horsf.}

87. Pomatorhinus montanus, Horsf., Linn. Trans., XIII. p. 165.

No essential difference is apparent between a specimen of this bird sent from Assam and the specimens obtained in the Island of Java, from which the original description was made.

Fam. Cuculide.

Genus Phoenicophaus, Vieill.

88. Phonicophaus tristis, Lesson?

"Bottle-green above; dark greenish-gray beneath; throat light greenish-gray, with black streaks; naked space around the eyes; superciliary streak white; tail with white tip; beak green. Thirteen inches long."-McClelland's MS.

No specimen having been found of this species, it will require further observations to determine its true character.

Genus Centropus, Ill.

89. Centropus Philippensis, Cuv.

"This species is very common in villages and cultivated rice-fields in Assam, and in low inundated lands along the banks of rivers. It is tame even in the most deserted places in which it is found, and seldom flies; but if pressed too closely, it rather forces its way into a thick hedge. It delights in moist humid climates, as is proved by the vast numbers of them which occur in the Sunderbunds, the only part of India exceptAssam in which I have seen them; but I believe they are also seen in the vicinity of Calcutta. I am informed that they are common at Maulmain on the Tenasserim coast, but I question if they are to be found in India further north-west than 
Bengal. They have a very peculiar suppressed note, resembling whono, uttered with such a degree of ventriloquism, that although you see the individual from which the sound escapes, you do not expect it as the cause. In passing through the Sunderbunds in April last, this whono was almost the only sound I heard, and I was at first induced to suppose that it proceeded from some concealed animal in my boat."-McClelland's $M S$.

90. Centropus lepidus, Horsf., Linn. Trans., XIII. p. 180.

Mr. McClelland's specimen is comparatively of a large size, but agrees in all particulars with the Cent. lepidus from Java.

\section{Genus Trogon.}

91. Trogon Hodgsonii, Gould, 'Monograph of Trogonidæ.'

Tribus Tenuirostres, Cuv.

Fam. Cinnyrider.

Genus Cinnyris, Cuv.

92. Cinnyris Assamensis. Cinn. nigrescens, capite suprà gulaque metallicè purpureis; dorso et colli lateribus intensè fuscescenti-rubris; plumis ad partem dorsi posteriorem flavido terminatis; uropygio, tectricibus cauda superioribus, rectricibusque cauda duabus intermediis metallicè purpureis; his elongatis ; abdomine et crisso flavido lavatis: rostro valdè incurvo, et quàm caput paululùm longiore.

This species is closely allied to Cinnyris Gouldia.

93. Cinnyris labecula. Punicea; guld pectoreque nitidissimis ; capite, plumis scapularibus, cauddque metallicè aureo viridibus; alis fuscis viridi nitentibus; subtùs cana.

Body three inches, tail two inches long.

Genus Arachnothera, Temm.

94. Arachnothera inornata, Temm., Pl. Col. LXXXIV. Fig. 2.

\section{Fam. Meliphagide.}

Genus Chloropsis, Jard. \& Selby.

95. Chloropsis chrysogaster. Suprà viridis, nitens; pectore abdomineque ex aurantio luteis ; guld, jugulo, lateribus colli, arcuque per oculos ducto atris, conterminio arctè circumscriptis; genis violaceis, maculd scapulari aruginosa; tectricibus, remigibus primoribus, rectricibusque nigris, nitore violaceo ; pileo aureo subnitente.

In the specimens of the female the black mark on the throat and neighbouring parts is not apparent; the spots on the chin and shoulders are obscure; but the general colour of the upper and lower parts is the same as in the male.

Genus Dic eum, Cuv.

96. Diccum erythronotum. Certhia erythronotos, Ind. Orn., I.290. Red-backed Creeper, Lath., Gen. Hist. of Birds, IV. 241. 'Souimanga à dos rouge,' Ois. dor,, II. 57. Pl. XXXV. 


\section{$2 \mathrm{BHL}$ Biodiversity Heritage Library}

1841. "LII.-A List of Mammalia and Birds collected in Assam." The Annals and magazine of natural history; zoology, botany, and geology 6, 450-461. https://doi.org/10.1080/03745484109442646.

View This Item Online: https://www.biodiversitylibrary.org/item/19590

DOI: https://doi.org/10.1080/03745484109442646

Permalink: $\underline{\text { https://www.biodiversitylibrary.org/partpdf/36786 }}$

\section{Holding Institution}

Natural History Museum Library, London

\section{Sponsored by}

Natural History Museum Library, London

\section{Copyright \& Reuse}

Copyright Status: Public domain. The BHL considers that this work is no longer under copyright protection.

This document was created from content at the Biodiversity Heritage Library, the world's largest open access digital library for biodiversity literature and archives. Visit BHL at https://www.biodiversitylibrary.org. 